\title{
AD genetic risk factors and tau spreading
}

\author{
Jesús Avila ${ }^{1,2 *}$, Alberto Gómez-Ramos ${ }^{1,2}$ and Marta Bolós ${ }^{1,2}$ \\ ${ }^{1}$ Centro de Investigación Biomédica en Red de Enfermedades Neurodegenerativas, Madrid, Spain, ${ }^{2}$ Centro de Biología \\ Molecular "Severo Ochoa" CSIC-UAM, Madrid, Spain
}

Keywords: endocytosis, tau proteins, genetic factors, PICALM, BIN1 bridging Integrator 1/amphiphysin-2 gene

Development of tau pathology is associated with progressive neuronal loss and cognitive decline. In the brains of Alzheimer's disease (AD) patients, tau pathology propagates according to an anatomically defined pattern with relatively uniform distribution, and contributes to cognitive decline in age-associated tauopathy (Braak and Braak, 1991; Saito et al., 2004). Recently, it has been revealed that tau, which is an intracellular protein, can appear in the extracellular space, likely due to an exocytosis mechanism. Such extracellular tau could then be internalized into neighboring cells in at least two different ways depending on its aggregation state. In the case of soluble monomeric or small oligomeric tau protein, the endocytosis appears to be clathrin dependent (reviewed in Rubinsztein, 2006). In contrast, larger aggregates of tau could bind heparin in the extracellular matrix and be internalized through macropinocytosis (Holmes et al., 2014). As a result of exocytosis and endocytosis, the spreading of tau can occur in various neurodegenerative diseases (tauopathies) including $\mathrm{AD}$. In this opinion article we have focused on the endocytosis mechanism.

Several genetic risk factors have been associated with a higher probability of developing sporadic Alzheimer's disease (SAD). The Alzheimer Association (http://www.alzforum.org/) has ranked the top six risk genes, shown in Table 1, based on genome-wide association studies (GWAS).

\section{OPEN ACCESS}

Edited by:

Elena Galea

Universitat Autònoma de Barcelona

Spain

Reviewed by:

Amy Pooler,

Nestlé Institute of Health Sciences,

Switzerland

Susanne Wegmann,

Massachusetts General Hospital, USA

*Correspondence:

Jesús Avila,

javila@cbm.csic.es

Received: 06 April 2015 Accepted: 08 May 2015

Published: 21 May 2015

Citation:

Avila J, Gómez-Ramos A and Bolós M

(2015) $A D$ genetic risk factors and tau

spreading.

Front. Aging Neurosci. 7:99

doi: 10.3389/fnagi.2015.00099

\section{Binding of SAD Genetic Risk Factors to Tau Protein}

The myc box-dependent-interacting protein 1, also known as bridging integrator 1 (BIN1), clusterin (clu), phosphatidylinositol binding clathrin assembly protein (PICALM), and apolipoprotein E (ApoE) are encoded by the BIN1, CLU, PICALM, and ApoE genes, respectively. These proteins are involved in the endocytosis of tau in either a direct (BIN1, CLU, and PICALM) or an indirect (ApoE) way, and all of them can also interact directly with tau (Chapuis et al., 2013; Tan et al., 2013; Holler et al., 2014; Moreau et al., 2014; Zhou et al., 2014). ApoE - mainly isoform ApoE3 - can bind efficiently to tau protein (Strittmatter et al., 1994). For BIN1, a novel brain-specific allele containing a $3 \mathrm{bp}$ insertion has been reported that may be responsible for the interaction of BIN1 with tau (Tan et al., 2013). Intracellular clusterin interacts with brain isoforms of BIN1 and with tau (Zhou et al., 2014). Less is known about the interaction of PICALM and tau. However, Moreau et al. (2014) carried out groundbreaking work describing the relationship between PICALM and tau. They showed how PICALM-dependent autophagy can modulate tau accumulation in cells. Impaired autophagy could result in neurotoxicity and, consequently, might also be related to the spreading of tau pathology.

ApoE and clu (ApoJ) are related proteins. They are involved in cholesterol and lipid transport and can regulate $A \beta$ endocytosis and $A \beta$ clearance (Bertrand et al., 1995; Nuutinen et al., 2009). They also share some cellular receptors (Leeb et al., 2014). For example, both ApoE and clusterin bind to heparin (Cardin et al., 1986; Pankhurst et al., 1998), which in turn may affect endocytic processes such as macropinocytosis. Thus, it can be hypothesized that ApoE (and ApoJ) may, in this indirect way, regulate tau endocytosis. 
TABLE 1 | The top six AD risk genes that interact with tau.

\begin{tabular}{|c|c|c|c|c|}
\hline Order & Gene & $\begin{array}{l}\text { Location } \\
\text { (GRCh38.p2 } \\
\text { assembly) }\end{array}$ & Polymorphism & References \\
\hline 1 & ApoE & $\begin{array}{l}\text { chr19:44905754- } \\
44909393\end{array}$ & ApoE 2,3,4 & $\begin{array}{l}\text { Strittmatter et al., } \\
\text { 1994; Grupe } \\
\text { et al., } 2007\end{array}$ \\
\hline 2 & $\mathrm{BIN} 1$ & $\begin{array}{l}\text { chr2:127048027- } \\
127107355\end{array}$ & rs 744373 & $\begin{array}{l}\text { Schellenberg and } \\
\text { Montine, } 2012\end{array}$ \\
\hline 3 & CLU & $\begin{array}{l}\text { chr:8: } 27596917- \\
27615031\end{array}$ & rs 11136000 & $\begin{array}{l}\text { Lambert et al., } \\
\text { 2009; Harold } \\
\text { et al., } 2009\end{array}$ \\
\hline 4 & ABCA7 & $\begin{array}{l}\text { chr19:1040101- } \\
1065572\end{array}$ & rs 3764650 & $\begin{array}{l}\text { Hollingworth } \\
\text { et al., } 2011\end{array}$ \\
\hline 5 & CR1 & $\begin{array}{l}\text { chr1:207496147- } \\
207640647\end{array}$ & rs 3818361 & $\begin{array}{l}\text { Lambert et al., } \\
2009\end{array}$ \\
\hline 6 & PICALM & $\begin{array}{l}\text { chr11:85957684- } \\
86069882\end{array}$ & rs 3851179 & $\begin{array}{l}\text { Harold et al., } \\
2009\end{array}$ \\
\hline
\end{tabular}

BIN1 has been ranked as the second most important susceptibility locus for developing SAD. It is expressed from a single locus located on human chromosome 2 (Ren et al., 2006). The gene is transcribed into nuclear RNA that can produce different proteins by alternative splicing (Pineda-Lucena et al., 2005). Some of the BIN1 isoforms, such as isoforms 1-6, are specifically located in the brain (Butler et al., 1997; Tsutsui et al., 1997; Wechsler-Reya et al., 1997). Furthermore, BIN1 is mainly expressed in neurons and some brain isoforms are mainly expressed in the axon initial segment (Holler et al., 2014).

\section{Extracellular Tau Endocytosis}

Extracellular soluble tau (monomers, small oligomers) or larger aggregates of tau can be endocytosed by neurons in several ways. It was shown that neurons have cell receptors for extracellular tau, for example M1 and M3 muscarinic receptors

\section{References}

Bertrand, P., Poirier, J., Oda, T., Finch, C. E., and Pasinetti, G. M. (1995). Association of apolipoprotein E genotype with brain levels of apolipoprotein E and apolipoprotein J (clusterin) in Alzheimer disease. Brain Res. Mol. Brain Res. 33, 174-178. doi: 10.1016/0169-328X(95)00097-C

Braak, H., and Braak, E. (1991). Neuropathological stageing of Alzheimer-related changes. Acta Neuropathol. 82, 239-259. doi: 10.1007/BF00308809

Butler, M. H., David, C., Ochoa, G. C., Freyberg, Z., Daniell, L., Grabs, D., et al. (1997). Amphiphysin II (SH3P9; BIN1), a member of the amphiphysin/Rvs family, is concentrated in the cortical cytomatrix of axon initial segments and nodes of ranvier in brain and around T tubules in skeletal muscle. J. Cell Biol. 137, 1355-1367. doi: 10.1083/jcb.137.6.1355

Cardin, A. D., Hirose, N., Blankenship, D. T., Jackson, R. L., Harmony, J. A., Sparrow, D. A., et al. (1986). Binding of a high reactive heparin to human apolipoprotein E: identification of two heparin-binding domains. Biochem. Biophys. Res. Commun. 29, 783-789. doi: 10.1016/S0006-291X(86)80489-2

Chapuis, J., Hansmannel, F., Gistelinck, M., Mounier, A., Van Cauwenberghe, C., Kolen, K. V., et al. (2013). Increased expression of BIN1 mediates Alzheimer genetic risk by modulating tau pathology. Mol. Psychiatry 18, 1225-1234. doi: $10.1038 / \mathrm{mp} .2013 .1$
(Gomez-Ramos et al., 2006, 2008). Once extracellular tau is bound to muscarinic receptors, it can be endocytosed in a clathrin-dependent process. This uptake mechanism could facilitate the spreading of tau from neuron to neuron, perhaps through synaptic transmission (De Calignon et al., 2012; Liu et al., 2012; Pooler et al., 2013). For aggregated tau, endocytosis is mediated by macropinocytosis (Holmes et al., 2014), in which components of the extracellular matrix, such as heparin sulfate, seem to play a role. Thus, two clearly different endocytic pathways have been proposed for the neuronal uptake of tau: receptor-clathrin dependent uptake of soluble tau species versus cell matrix-dependent endocytosis of tau aggregates.

In SAD, an increase in the expression of BIN1 and PICALM has been described, which could induce an increase in tau clathrin-mediated endocytosis. This could lead to the accumulation of soluble tau in tau recipient cells and may result in a toxic effect. On the other hand, a decrease in the level of clusterin, which like ApoE, is a heparin-binding protein, could enhance the binding of aggregated tau to the extracellular matrix and hence also enhance its endocytosis, resulting in a toxic effect in the recipient cell.

In summary, it is remarkable that four of the main genetic risk factors for Alzheimer's disease are tau-binding partners. Identifying how these risk factors affect tau propagation may unveil new therapeutic targets to stop or delay progression of pathology. For example, one possible way to reduce tau endocytosis and subsequent spreading of tau pathology may be to decrease neuronal levels of BIN1 and PICALM (which are increased in Alzheimer's disease) in early stages of the disease. Future research is therefore needed to better understand the interactions of tau with these proteins.

\section{Acknowledgments}

This work was supported by grants of MINECO (SAF2014-5040-P), Spain and CIBERNED.

De Calignon, A., Polydoro, M., Suarez-Calvet, M., William, C., Adamowicz, D. H., Kopeikina, K. J., et al. (2012). Propagation of tau pathology in a model of early Alzheimer's disease. Neuron 73, 685-697. doi: 10.1016/j.neuron.2011.11.033

Gomez-Ramos, A., Diaz-Hernandez, M., Cuadros, R., Hernandez, F., and Avila, J. (2006). Extracellular tau is toxic to neuronal cells. FEBS Lett. 580, 4842-4850. doi: 10.1016/j.febslet.2006.07.078

Gomez-Ramos, A., Diaz-Hernandez, M., Rubio, A., Miras-Portugal, M. T., and Avila, J. (2008). Extracellular tau promotes intracellular calcium increase through M1 and M3 muscarinic receptors in neuronal cells. Mol. Cell. Neurosci. 37, 673-681. doi: 10.1016/j.mcn.2007.12.010

Grupe, A., Abraham, R., Li, Y., Rowland, C., Hollingworth, P., Morgan, A., et al. (2007). Evidence for novel susceptibility genes for late-onset Alzheimer's disease from a genome-wide association study of putative functional variants. Hum. Mol. Genet. 16, 865-873. doi: 10.1093/hmg/ddm031

Harold, D., Abraham, R., Hollingworth, P., Sims, R., Gerrish, A., Hamshere, M. L., et al. (2009). Genome-wide association study identifies variants at CLU and PICALM associated with Alzheimer's disease. Nat. Genet. 41, 1088-1093. doi: 10.1038/ng.440

Holler, C. J., Davis, P. R., Beckett, T. L., Platt, T. L., Webb, R. L., Head, E., et al. (2014). Bridging integrator 1 (BIN1) protein expression increases in the Alzheimer's disease brain and correlates with neurofibrillary 
tangle pathology. J. Alzheimers. Dis. 42, 1221-1227. doi: 10.3233/JAD132450

Hollingworth, P., Harold, D., Sims, R., Gerrish, A., Lambert, J.-C., Carrasquillo, M. M., et al. (2011). Common variants at ABCA7, MS4A6A/MS4A4E, EPHA1, CD33 and CD2AP are associated with Alzheimer's disease. Nat. Genet. 43, 429-435. doi: 10.1038/ng.803

Holmes, B. B., Furman, J. L., Mahan, T. E., Yamasaki, T. R., Mirbaha, H., Eades, W. C., et al. (2014). Proteopathic tau seeding predicts tauopathy in vivo. Proc. Natl. Acad. Sci. U.S.A. 111, E4376-E4385. doi: 10.1073/pnas.1411649111

Lambert, J.-C., Heath, S., Even, G., Campion, D., Sleegers, K., Hiltunen, M., et al. (2009). Genome-wide association study identifies variants at CLU and CR1 associated with Alzheimer's disease. Nat. Genet. 41, 1094-1099. doi: 10.1038/ng.439

Leeb, C., Eresheim, C., and Nimpf, J. (2014). Clusterin is a ligand for apolipoprotein E receptor 2 (ApoER2) and very low density lipoprotein receptor (VLDLR) and signals via the Reelin-signaling pathway. J. Biol. Chem. 289, 4161-4172. doi: 10.1074/jbc.M113.529271

Liu, L., Drouet, V., Wu, J. W., Witter, M. P., Small, S. A., Clelland, C., et al. (2012). Trans-synaptic spread of tau pathology in vivo. PLoS ONE 7:e31302. doi: 10.1371/journal.pone.0031302

Moreau, K., Fleming, A., Imarisio, S., Lopez Ramirez, A., Mercer, J. L., JimenezSanchez, M., et al. (2014). PICALM modulates autophagy activity and tau accumulation. Nat. Commun. 5, 4998. doi: 10.1038/ncomms5998

Nuutinen, T., Suuronen, T., Kauppinen, A., and Salminen, A. (2009). Clusterin: a forgotten player in Alzheimer's disease. Brain Res. Rev. 61, 89-104. doi: 10.1016/j.brainresrev.2009.05.007

Pankhurst, G. J., Bennett, C. A., and Easterbrook-Smith, S. B. (1998). Characterization of the heparin-binding properties of human clusterin. Biochemistry 37, 4823-4830. doi: 10.1021/bi972367v

Pineda-Lucena, A., Ho, C. S., Mao, D. Y., Sheng, Y., Laister, R. C., Muhandiram, R., et al. (2005). A structure-based model of the c-Myc/Bin1 protein interaction shows alternative splicing of Bin1 and c-Myc phosphorylation are key binding determinants. J. Mol. Biol. 351, 182-194. doi: 10.1016/j.jmb.2005.05.046

Pooler, A. M., Phillips, E. C., Lau, D. H., Noble, W., and Hanger, D. P. (2013). Physiological release of endogenous tau is stimulated by neuronal activity. EMBO Rep. 14, 389-394. doi: 10.1038/embor.2013.15

Ren, G., Vajjhala, P., Lee, J. S., Winsor, B., and Munn, A. L. (2006). The BAR domain proteins: molding membranes in fission, fusion, and phagy. Microbiol. Mol. Biol. Rev. 70, 37-120. doi: 10.1128/MMBR.70.1.37-120.2006
Rubinsztein, D. C. (2006). The roles of intracellular protein-degradation pathways in neurodegeneration. Nature 443, 780-786 doi: 10.1038/nature05291

Saito, Y., Ruberu, N. N., Sawabe, M., Arai, T., Tanaka, N., Kakuta, Y., et al. (2004). Staging of argyrophilic grains: an age-associated tauopathy. J. Neuropathol. Exp. Neurol. 63, 911-918.

Schellenberg, G. D., and Montine, T. J. (2012). The genetics and neuropathology of Alzheimer's disease. Acta Neuropathol. (Berl.) 124, 305-323. doi: 10.1007/s00401-012-0996-2

Strittmatter, W. J., Saunders, A. M., Goedert, M., Weisgraber, K. H., Dong, L. M., Jakes, R., et al. (1994). Isoform-specific interactions of apolipoprotein E with microtubule-associated protein tau: implications for Alzheimer disease. Proc. Natl. Acad. Sci. U.S.A. 91, 11183-11186. doi: 10.1073/pnas.91.23.11183

Tan, M. S., Yu, J. T., and Tan, L. (2013). Bridging integrator 1 (BIN1): form, function, and Alzheimer's disease. Trends Mol. Med. 19, 594-603. doi: 10.1016/j.molmed.2013.06.004

Tsutsui, K., Maeda, Y., Seki, S., and Tokunaga, A. (1997). cDNA cloning of a novel amphiphysin isoform and tissue-specific expression of its multiple splice variants. Biochem. Biophys. Res. Commun. 236, 178-183. doi: 10.1006/bbrc. 1997.6927

Wechsler-Reya, R., Sakamuro, D., Zhang, J., Duhadaway, J., and Prendergast, G. C. (1997). Structural analysis of the human BIN1 gene. Evidence for tissuespecific transcriptional regulation and alternate RNA splicing. J. Biol. Chem. 272, 31453-31458. doi: 10.1074/jbc.272.50.31453

Zhou, Y., Hayashi, I., Wong, J., Tugusheva, K., Renger, J. J., and Zerbinatti, C. (2014). Intracellular clusterin interacts with brain isoforms of the bridging integrator 1 and with the microtubule-associated protein Tau in Alzheimer's disease. PLOS ONE 9:e103187. doi: 10.1371/journal.pone. 0103187

Conflict of Interest Statement: The authors declare that the research was conducted in the absence of any commercial or financial relationships that could be construed as a potential conflict of interest.

Copyright (c) 2015 Avila, Gómez-Ramos and Bolós. This is an open-access article distributed under the terms of the Creative Commons Attribution License (CC BY). The use, distribution or reproduction in other forums is permitted, provided the original author(s) or licensor are credited and that the original publication in this journal is cited, in accordance with accepted academic practice. No use, distribution or reproduction is permitted which does not comply with these terms. 